\title{
The Role of Teachers in Building National Character Values through Traditional Games for Elementary School Students
}

\section{Siti Sholiha Nurfaidah ${ }^{*}$, Azis Lukman Praja ${ }^{2}$, Devi Rahmiati ${ }^{3}$}

1,2,3 PGSD FKIP Universitas Pasundan

\section{A R T I C L E I N F O}

Article history:

Received 20 August 2018

Received in revised form

15 September 2018

Accepted 24 October 2018

Available online 30

November 2018

\section{Keywords:}

The role of the teacher, the character of the nation, traditional games.

\section{A B S T R A C T}

Rapid technological and information developments have impacted changes in various lines of life. The big impact that arises from the changes that occur is the decline in the values of the nation's character. The problem solving effort is by providing guidance in improving the ability of educators in shaping the values of the national character of elementary school students. The targets in this activity are the Teacher Working Group (KKG) in SD PBI and KKG in SDN 208 Luginasari. The method used in the form of organizing seminars and workshops on the role of teachers in building national character values to elementary school students. The activity was carried out quite well. Teachers are given debriefing and skills to carry out learning activities that contain character education through traditional game intermediaries. Suggestions for the achievement of the objectives of this activity is that assistance is still needed for the teacher so that the teachers can consistently transform their knowledge and skills in the path that we all expect.

\footnotetext{
* Corresponding author.

E-mail addresses: sitinurfanurfaidah@unpas.ac.id (Siti Sholiha Nurfaidah)
} 


\section{Introduction}

Character education is education that cannot be ruled out. Until now this education is very important for us, especially for children who are still in the world of education. Because in the world of education, character education can be used as a place or process to form a better child's personality. This education aims to shape Indonesian people who are moral, intelligent and rational, form innovative and hardworking, optimistic and trusting, and patriotic people. Thus education that is very needed today is education that can integrate character education in the learning process. So that all dimensions of child development can be optimally balanced.An educational model that integrates character education in a learning process like this is oriented towards the formation of children as whole human beings. So that the learning approach centered on student activities is very appropriate to support the learning process in question. According to Fatim Zahroh (2017) This approach is able to create an atmosphere that is more democratic, fair, humane, fun, arouses interest in learning, stimulates the emergence of inspiration, imaginative, creative, innovative and vibrant spirit. And this approach is also able to make the quality of students become superior not only in the cognitive aspects, but also in their character. Children who excel in character will be able to deal with problems and challenges in their lives. Thus indirectly educators who only prioritize cognitive aspects have killed the child's character.

As for the results of the situation analysis in the field, the influence of western culture in the urban environment has dominated enough so that it has an impact on the emergence of problems of decreasing national character values. One of the influences that emerged was the rapid development of modern games in Indonesian society. Therefore, the existence of traditional games increasingly decreases even tends to be forgotten. The loss of traditional games means the values of the nation's character are lost. Traditional games are actually as old as the age of culture in our country. They are an integral part of that culture. Indonesia, which is very rich in various cultural heritage, is very rich in various traditional games. Traditional games also teach the values of cooperation, sportsmanship, honesty and creativity. Not to mention some modern games contain negative content, such as elements of violence, sadism is also pornography. So that gradually this influence will have an impact on the loss of national character.

The progress of a nation is determined by the ability of its educators to shape the character of future generations in the future. Teachers have a very important role in improving the quality of education in schools, especially at the level of basic education which provides the ability of students with basic knowledge and skills. Therefore, the ability or competence of the teacher needs to always be fostered and improved, so that in carrying out their duties and responsibilities can create optimal performance of an educator and can improve their competence. As an effort to foster or improve the ability of teachers in primary schools, one of them is through the formation of Teacher Working Groups (KKG). The KKG is a professional activity forum or forum for elementary school / madrasah Ibtidaiyah teachers at the cluster or sub-district level consisting of a number of teachers from a number of schools.

Based on the above explanation, the values of national character in students can also be built through the guidance of the KKG. The group that became our target was the KKG in the middle of the city of Bandung, namely the KKG in SD BPI and SDN 208 Luginasari Sukagalih Bandung City, West Java Province. Given that the influence of western culture in the urban environment has been quite dominant. Students in this environment already have a very close relationship with the use of information technology products that have an impact on the emergence of problems of decreasing national character values.

\section{Methods}

The method used in the community partnership program (PKM) is in the form of organizing seminars and outreach about the role of teachers in enhancing national character values to elementary school students and carrying out traditional game workshops in order to build and improve and realize the education character program "Bandung Masagi "which is suitable and in line with the 2013 Curricula without leaving the Sundanese character values.

The stages of implementing the Community Partnership Program (PKM) are as follows:

1. Preparation Stage

a. Observation

Observations were made by the team proposing the Community Partnership Program (PKM) with the aim to find out the preliminary data about the potential role of the teacher in introducing traditional games in improving the values of the nation's character, especially in Elementary School students in Bandung City by interviewing related parties on both the partner. 


\section{b. Coordination}

Coordinate the two partners to conduct seminars, socialization and workshops for relevant parties (Principals and Teacher Working Groups) in this Community Partnership Program (PKM).

c. Determination of Seminar and Workshop Activities

In collaboration with the Principal, planning the seminar and workshop implementation includes the determination of the committee, the schedule of seminars and workshops, the time and place for conducting seminars and workshops, seminar materials, and the assistance schedule or workshop as stated and implied in the Memorandum of Understanding (MoU) made by both parties involved in this Community Partnership Program (PKM). In addition, the team collaborated with outsiders such as the Bandung City Education Office to contact relevant resource persons with the title and purpose of the Community Partnership Program (PKM) so that these activities could be carried out properly and in accordance with the objectives of this PKM.

d. Preparation of Seminar and Workshop Materials

Preparing materials for seminars and workshops covering the role of the teacher in introducing the influence of the game in developing the values of the nation's character, forming and directing games, especially traditional games in enhancing national character values in accordance with the 2013 Curriculum and the Mayor of Bandung regulations on Character Education known as the term "Bandung Masagi".

2. Implementation Phase

In the seminar activities carried out by the Community Partnership Program Team (PKM) using lecture methods, interactive discussions, and ended with traditional game simulations. The speakers presented in this activity were the Community Partnership Program Team (PKM), namely Ms. Ifa Hanifah Misbach, M.A., a psychologist, she was the initiator of the Mayor's Regulation (Perwal) on Character Education "Bandung Masagi", and Mrs. Dr. Nike Kamarubiani, M.Pd., he is the drafting team of Mayor Regulation (Perwal) about Character Education "Bandung Masagi" and leader at Cipaku Bandung Eco Bamboo which is engaged in the preservation of Sundanese culture.

3. Evaluation and Report Writing Phase

Evaluation is carried out by examining the results / documentation of seminars and workshops on the role of teachers in shaping and directing games, especially traditional games in enhancing national character values by the team proposing the Community Partnership Program (PKM). After obtaining data / evaluation results from the workshop, a report was made in accordance with the guidelines for the implementation of Research and Community Service at Higher Education Edition XI 2017 from the Directorate of Research and Community Service Directorate General of Research and Development Strengthening the Ministry of Research, Technology and Education High

\section{Results And Discussion}

\section{Results}

This PKM activity is carried out based on an analysis of the situation globally that there has been a decline in the nation's morals and character due to technological and information progress. Then a situation analysis was carried out specifically for our two PKM partners who showed similar feomena. Therefore, one of the efforts to build the values of the character of this nation is through the process of teaching and learning in formal education. Teachers as facilitators at school certainly need to know more than their students. For this reason, the next PKM program activity is the socialization of the role of the teacher in an effort to build the values of the nation's character through traditional games for students in the school environment through seminars and workshops or mentoring.

Based on a joint agreement, the socialization activities were carried out through seminars held on Saturday, July 21, 2018. Participants who attended the seminar consisted of BPI Elementary School teachers, SDN 208 Luginasari Sukagalih teachers, FKIP UNPAS lecturers, and FKIP UNPAS students . Besides that the activity was carried out because it was supported by the committee (both lecturers, students, and staff of FKIP UNPAS) and this seminar invited speakers (PKM team and practitioners), so that the entire event consisted of \pm 70 people. 


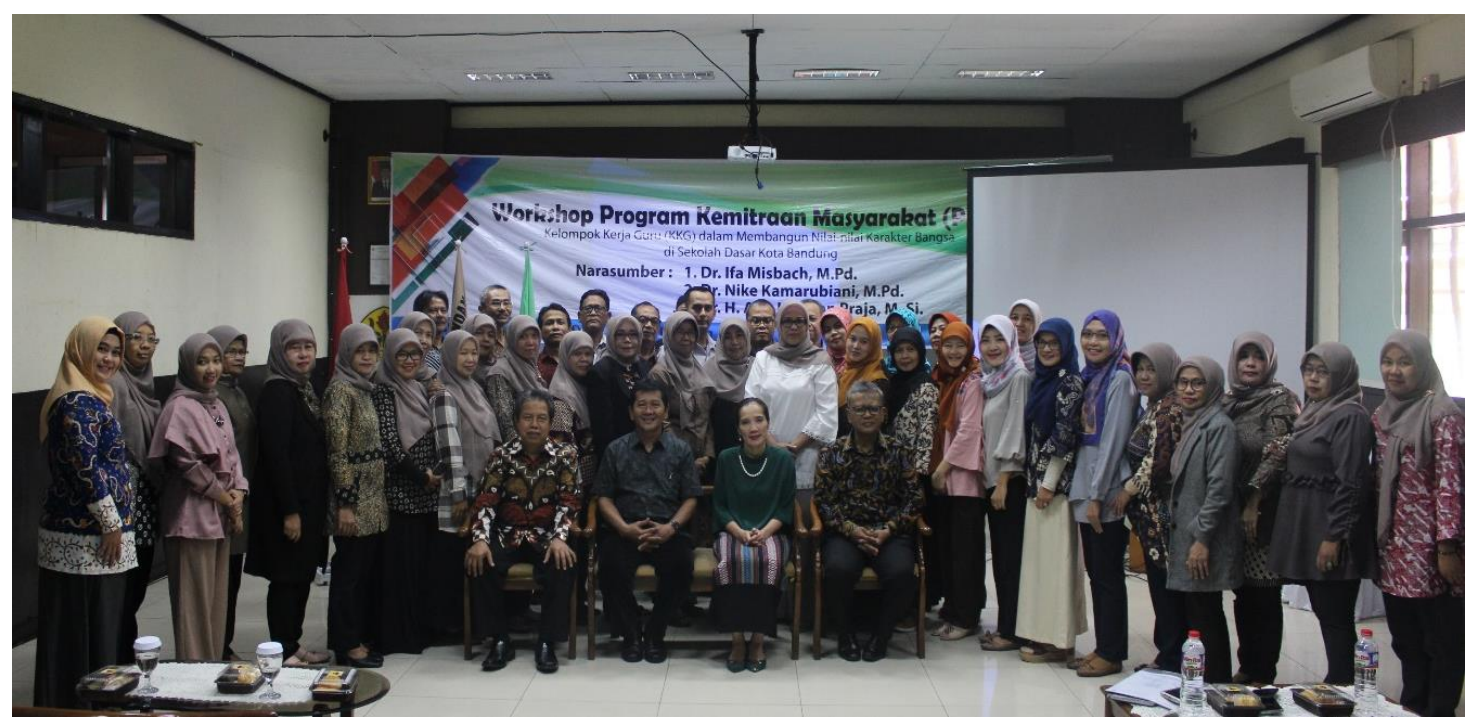

Figure 1. Photo of All Activity Fillers

\section{Discussion}

Based on the results of UNICEF's research, 2014 (Kamarubiani, 2018) states that 30 million Indonesian children aged 10-19 are internet users. Most of them are exposed to pornographic content, when they appear inadvertently or in the form of advertisements with vulgar nuances. In addition, parents in Indonesia lag behind their children in mastering digital media. A similar phenomenon was obtained from the research results of the Kita and Buah Hati Foundation, 2013 (Kamarubiani, 2018) that 76\% of the 2,818 students in grades 4-6 SD had accessed pornographic material online through mobile devices, especially through smartphones.

The impact of pornography is believed to be closely related to an increase in cases of sexual violence in children. Moreover, the tendency of perpetrators of sexual violence is those who are accustomed to consuming pornographic videos. This was further strengthened by cases of sexual violence which had increased from year to year according to data from the Child Protection Commission 20102014 (Kamarubiani, 2018), such as: there were 1,407 cases in 2011; 1,635 cases in 2012; da 2,070 in 2013. This certainly has become a real picture that Indonesia is faced with the threat of moral degradation. This kind of thing cannot be allowed to continue until it becomes more complicated. We as educators need to go down directly to overcome this problem.

Seminar and workshop activities are used as a method to solve the problem of decreasing national character values. The activity emphasizes more on the socialization of the role of the teacher in shaping the values of the nation's character through traditional games. In this activity was described the program "Bandung Masagi" which is a culture education model based on the values of local wisdom. The vision of this program is "To create Bandung City students who have superior character, have noble character, love the motherland, care for the environment and are cultured Sundanese, which based on the philosophy of picking up, taking care, caring and taking notes." this has been used as a pilot project for the implementation of character education in Indonesia by the Minister of Education and Culture of the Republic of Indonesia (Miftah, 2016).

Besides that, also explained the values of the nation's character that can be built from a traditional game. And in this activity emphasized the need for a program that can establish cooperation and alignment of education programs in education, family and society units as a center of education in building a conducive education ecosystem to develop the character and culture of achievement for students.

In addition to seminar activities, a series of other PKM activities are mentoring. The assistance referred to in our PKM program is in the form of workshops, namely the follow-up to the seminar activities that have been conducted. The workshop conducted is an application of the provision of knowledge that has been presented in the seminar activities. In this mentoring or workshop, it discusses how teachers design plans for learning activities that insert traditional games in order to build the values of the nation's character that are adapted to the implementation of the 2013 Curriculum in Elementary Schools in the RPP. In addition, in this assistance traditional simulation games were carried out with facilitators from Eco Bamboo Cipaku Setiabudhi Bandung. 

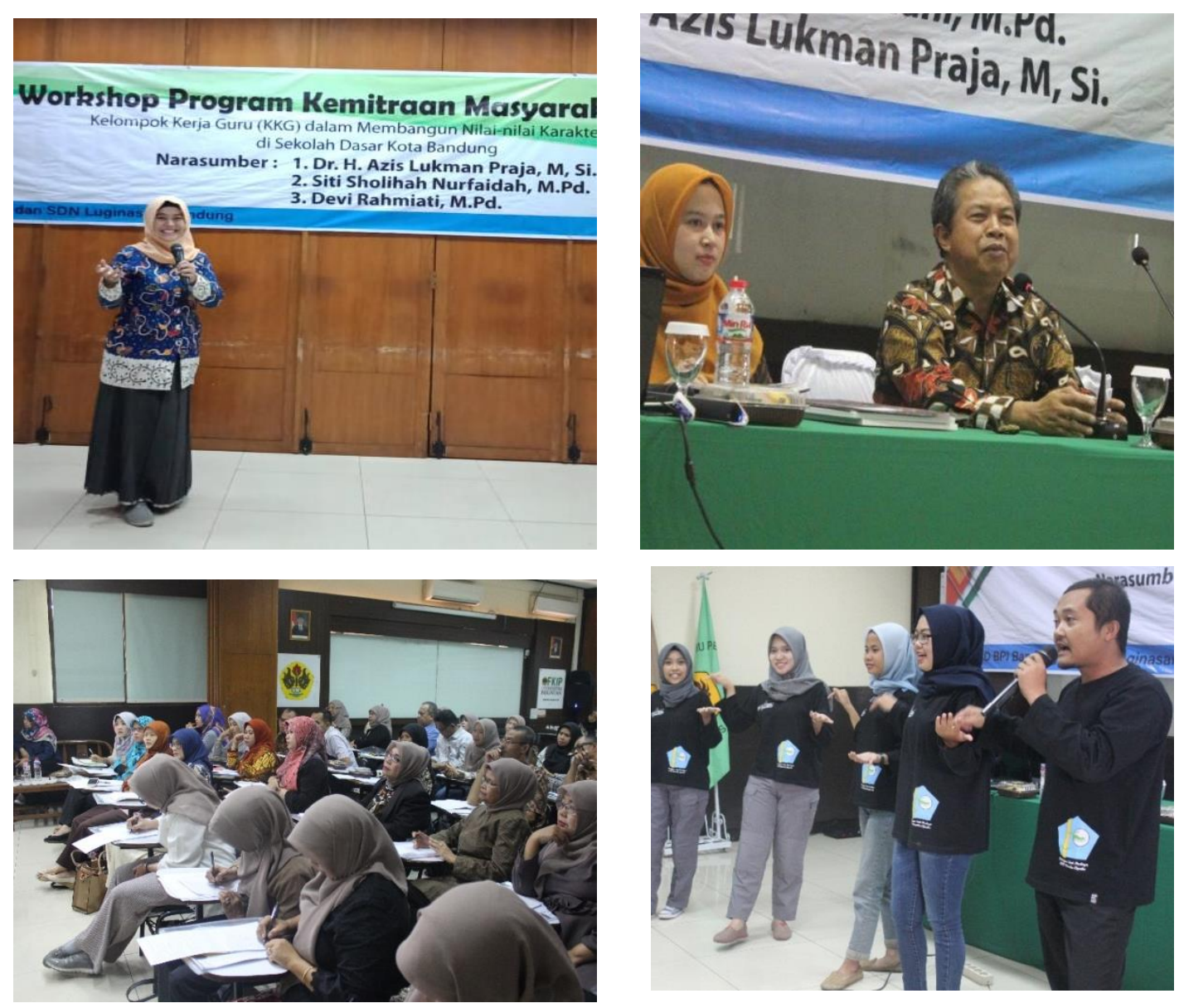

Figure 2. Photo of Assistance or Workshop Activities

\section{Conclusion and Recommendations}

Seminar and workshop activities are carried out quite well. The enthusiasm of all participants seemed very good. Teachers are given debriefing and skills to carry out learning activities that contain character education through traditional game intermediaries.

Suggestions for the achievement of the objectives of this activity is that assistance is still needed for the teacher so that the teachers can consistently transform their knowledge and skills in the path that we all expect. In addition, activities like this need to be disseminated to a wider audience not fixated on the Teacher Working Groups in urban areas.

\section{Refrence}

Kamarubiani, Nike. (2018). Best Practice Kemitraan Sanggar Seni dengan Sekolah dalam Program Pendidikan Karakter. Bahan tayang seminar: Tidak diterbitkan

Miftah. (2016). Bandung Masagi Diapresiasi Mendikbud. Tersedia. [online]: https://portal.bandung.go.id/posts/2016/07/19/LVEY/bandung-masagi-diapresiasi-mendikbud. (20 Agustus 2018)

Zahroh, Fatim. (2017). Pentingnya Pendidikan Karakter dalam Dunia Pendidikan.Tersedia. [online]: https://www.kompasiana.com/fatiiim/590ff69fa5afbd8508fef994/pentingnya-pendidikankarakter-dalam-dunia-pendidikan. (20 Agustus 2018) 